\title{
ANALYSIS OF INDONESIA'S EXPORTS \& IMPORTS IN THE ASIAN REGION: BEFORE AND DURING THE COVID-19 PANDEMIC
}

\section{Ngatno $^{1+}$ Apriatni Endang Prihatiningsih $^{2}$}

\author{
${ }_{1,2}^{1,2}$ epartement of Business \\ Semarang Indonesia. \\ 'Email:ngatnoffisip@yahoo.co.id \\ Email:apriatni_ep@yahoo.co.id
}

Administration, Diponegoro University,

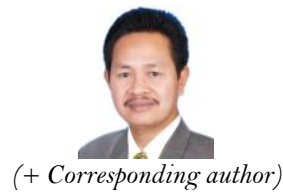

Article History

Received: 16 August 2021 Revised: 27 September 2021 Accepted: 22 October 2021 Published: 18 November 2021

\section{Keywords}

Asian

Export

Import

Covid-19

International trade

JEL Classification: F13, F14, F18, F 40.

\section{ABSTRACT}

The purpose of this study is to identify the impact of the Covid-19 pandemic on Indonesia's export and import activity in the Asian region. Data on exports and imports from February 2019 to March 2020 (before the pandemic) and from April 2020 to May 2021 (during the pandemic) was collected from the Indonesian Central Statistics Agency portal. The results show that the impact of the Covid-19 pandemic does not always decrease Indonesia's exports and imports in countries in the Asian region. For exports, out of 51 countries, only 18 decreased significantly, 14 countries decreased insignificantly, and 19 countries increased. On the import side, out of the same 51 countries, only 11 experienced a significant decline, 24 countries experienced an insignificant decrease, and 19 countries experienced an increase. The Indonesian government must implement various policies that can protect and encourage exports by providing fiscal stimulus, diversifying trading partners, deregulation, and industrial downstream, among others. Further research needs to be carried out on how the effects of the pandemic changed import and exports according to product type and how the severity of the pandemic affects within a country affected export and import activities.

Contribution/Originality: This study is one of very few studies which have investigated the effect of the Covid19 pandemic on Indonesia's exports and imports in the Asian region.

\section{INTRODUCTION}

The coronavirus (Covid-19) pandemic has spawned an unprecedented level of social and economic crisis across the globe. There is little doubt that 2020 will be known as the year of Covid-19. As of July 25, 202 1, the virus that emerged in China has infected more than 194 million people and it has killed 4,167,937 people. To prevent the spread of the virus, every country has introduced social distancing and strict containment measures. Human behavior is a prime factor in the success of these measures, and individuals respond differently to these measures. Several preventive measures, such as social distancing, washing hands and wearing masks, have been implemented alongside strict lockdowns.

Covid-19 containment policies have harmed global economic activity. The International Monetary Fund projected a $4.4 \%$ decline in global gross domestic product (GDP) in 2020, the highest decrease in 40 years (IMF, 2020), which is better than in 2020 where it was negative $3.3 \%$ due to the pandemic. The economies of developing countries in Asia are predicted to grow the most in 2021, which is $8.6 \%$. The Indonesian government has revised Indonesia's economic growth target to be in the range of $3.7 \%$ to $4.5 \%$ from $4.3 \%$ to $5.3 \%$. The decline in the growth target was based on government policies imposing a lockdown that limited the mobility of people and 
goods, and resulted in slowing trade flows at the local, regional and international levels. A consequence of the lockdown is the disruption of supply chains which, in turn, creates a negative supply (Richard Baldwin \& Tomiura, 2020). Measures, such as workplace closures, border closures, and international travel restrictions, have hampered global trade flows, resulting in increased trade costs and delays or prohibitions across borders (Maliszewska, Mattoo, \& van der Mensbrugghe, 2020). Furthermore, the Covid-19 pandemic is projected to reduce global GDP and international trade by at least $4.9 \%$ and 13\%, respectively, in 2020 (IMF, 2020; WTO, 2020b).

Although most observers state that the Covid-19 pandemic has harmed the economies of all countries, the impact of the pandemic is still inconclusive. However, it has been stated that the pandemic has not necessarily harmed countries (Socrates \& Lashitew, 2020). Additionally, existing studies on the impact of the pandemic almost entirely focus on financial markets (Apergis \& Apergis, 2020; Haroon \& Rizvi, 2020; Narayan, 2020; Phan \& Narayan, 2020; Zhang, $\mathrm{Hu}$, \& Ji, 2020); meanwhile, research on international trade activities is still limited. Previous research which examined the impact of the Covid-19 pandemic on international trade activities showed that the implementation of a lockdown by Kenya's trading partners had a positive effect on exports but a negative impact on imports (Socrates \& Lashitew, 2020). Weekly imports from countries that imposed lockdown measures fell by an average of $28 \%$, while exports to those countries increased by $12 \%$. Furthermore, Fugazza (2020) states that differences in import demand shocks at the product level have different effects at the country level.

The existence of this knowledge gap requires a study on whether the Covid-19 pandemic has disrupted export and import activities. To date, there is limited evidence on the nature and extent of this influence on trade performance, particularly in developing countries. This paper aims to understand how the impact of the pandemic has affected Indonesia's export and import trade activities in the Asian region. In 2019, Indonesia's export and import trade activities in the Asian region comprised $73.97 \%$ of all Indonesian exports and more than $77.10 \%$ for imports.

\section{LITERAURE REVIEW}

\subsection{The Effects of the Covid-19 Pandemic on Economic Growth}

The Covid-19 pandemic has disrupted the economy by causing labor shortages, a large number of redundancies, production cuts, and even factory closures, leaving many employers and workers with reduced or no income. Consequently, this has led consumers and companies to reduce or delay spending. These conditions make the outlook for economic growth very uncertain, with annual global GDP growth projected to decline to $2.4 \%$ in 2020 from 2.9\% in 2019, and even to a negative figure in the first quarter of 2020 (OECD, 2020). However, if the effects of the virus outbreak fade as assumed and policy actions are well-targeted, the impact on global GDP growth should recover to $3.25 \%$ by 2021 (OECD, 2020). The GDP of developing countries is expected to fall by $2.5 \%$, and by $1.9 \%$ in high-income countries. The highest GDP losses under the global pandemic scenario are expected to occur in southeast Asian, Eastern, and Pacific countries, such as Cambodia (3.2\%), Singapore (2.1\%), Hong Kong SAR, China (2.3\%), Thailand (3\%), Vietnam (2.7\%), and Malaysia (2.1\%), due to their relatively deep integration through trade and their direct impact on tourism. Meanwhile, the pandemic is projected to reduce international trade by at least $13 \%$ by the end of 2020 (IMF, 2020).

The Asian Development Bank estimates that the Indonesian economy will contract by $1 \%$ in 2020 amid the pandemic before climbing back to a 5.3\% growth rate in 2021 (ADB, 2020a). The 2020 contraction is Indonesia's first economic downturn since the 1997-98 Asian financial crisis occurred amid overall negative growth projections in the developing Asian regions. However, Indonesia's economic growth was revised downward to $-6.1 \%$ in 2020 with a recovery of $4.1 \%$ in 2021 (ADB, 2020b). Furthermore, Wicaksono \& Uluwiyah (2020) stated that the Covid19 pandemic had a significant impact on macroeconomic conditions, was a source of shock for Indonesia's macroeconomy, and also had a negative impact on macroeconomic indicators. 


\subsection{The Effects of the Pandemic on International Trade Activity}

Export and import, or international trade, is the exchange of goods and services across national borders. Most economists agree about the desirability of liberal trade, which is based on the theory of comparative advantage between countries (Feenstra, 2003). The state will export advantage goods and import cheaper goods. Export and import activities are closely related to GDP and the economy of a country (McConnell, Brue, \& Flynn, 2009). Export performance reflects a country's domestic economic development (Millath \& Thowseaf, 2016). The ups and downs of global trade (exports and imports) can be influenced by the economic environments, and specifically, a global crisis (Ahmed, Gasaymeh, \& Mehmood, 2017). The global crisis brought trade collapse (Baldwin, 2009; Eaton, Kortum, Neiman, \& Romalis, 2011) and reduced exports (Ahn, Amiti, \& Weinstein, 2011; Chor \& Manova, 2012).

The Covid-19 pandemic has affected not only a new pattern of world trade but also trade relations and globalization (Barua, 2020). The pandemic has also disrupted many productive activities in Asia, Europe, the United States, and other parts of the world. The lockdowns have resulted in simultaneous supply and demand shocks affecting almost all sectors. From the export side, the primary export destination countries will hold or cancel orders. This disruptive activity can reduce the demand for goods and services (ECLAC, 2020). There has been an increase in trade policy activism, so many countries have imposed export bans and restrictions to reduce domestic shortfalls at the national level (Evenett, 2020). More than 60 countries have restricted exports of essential goods and increased agricultural and food products (OECD, 2020). As of April 24, 2020, more than 80 countries and customs territories have imposed export bans or restrictions in response to the pandemic (WTO, 2020a). This shock in foreign demand has led many countries to restrict imports to support national production, but such import bans reduce consumer availability to international companies (Kaneda, Kubota, \& Tanaka, 2021).

The Covid-19 pandemic caused global trade to fall by $5.5 \%$ in October 2020 compared to the same period in 2019 (UNCTAD, 2020). Most countries experienced a decline in international trade in the second quarter of 2020. The sharpest declines occurred in West Asia and South Asia, where imports fell by 35\%, and exports fell by $41 \%$. The decline in trade in 2020 in the Asian region was $4.5 \%$ for exports and $4.4 \%$ for imports. Vidya \& Prabheesh (2020) revealed that there tends to be a significant decline in trade in developing countries due to the devastating impact of the Covid-19 pandemic. China's 'central' position in the trade network is unaffected by the pandemic, but instead, there will be a drastic decline in trade for most economies until the end of December 2020.

In developing countries, the economic downturn is felt by countries that rely on commodity exports due to falling prices and demand (Jackson, Weiss, Schwarzenberg, \& Nelson, 2021). In line with that, the World Bank stated that the economic impact of the global recession would mostly fall on developing economies, especially those that depend on commodity exports.

As an open economy country, Indonesia is dependent on international trade, and its 2018 imports and exports contributed 22.06\% and 20.97\%, respectively, to the GDP (WITS, 2018). To suppress the spread of Covid-19, Indonesia has imposed large-scale social restrictions (LSSR) and restrictions on community activities (CAR) in almost all parts of the country. Restrictions on these activities can disrupt livelihoods and supply chains, so the government prioritized health and consumption goods. Wicaksono \& Uluwiyah (2020) showed that the number of Covid-19 cases in a country and human mobility affect exports and imports. The Indonesian Central Board of Statistics noted that from January to November 2020, Indonesia's exports fell by $4.22 \%$ compared to the same period in 2019, while its imports from January to November 2020 decreased by $18.91 \%$ compared to same period in 2019. In addition, the Covid-19 pandemic has had a domino effect on the Indonesian economy, starting with a decline in Indonesia's exports and imports as a result of the economic downturn in the global value chain (GVC) countries, especially China, Korea and Japan. Based on this elaboration, it is evident that the Covid-19 pandemic has harmed Indonesian exports to and imports from other countries in the Asian region. 


\section{METHOD}

Data were collected by accessing the portal of the Indonesian Central Board of Statistics. Export and import data from February 2019 to March 2020 represents data before the pandemic, while data from April 2020 to May 2021 represents data during the pandemic. The data analysis was conducted descriptively and inferentially. An independent sample t-test was used to test the difference between the average exports and imports before and during the pandemic. The cut-off value limit used is $10 \%$ with a t-value 1.705 , or by checking the lower and upper values of the confidence interval of the difference past zero.

\section{RESULT AND DISCUSSION}

\subsection{Descriptive Statistics}

To provide an overview of the Indonesian export and import data sample from each Asian country, the maximum, minimum and average values of the export and import data were obtained for each month before and during the Covid-19 pandemic. The data are grouped by regions, namely Southeast Asia, East Asia, South Asia, Central Asia and West Asia.

\subsection{Indonesia's Exports and Imports in the Southeast Asia Region}

Figure 1 illustrates Indonesia's export and import performance in the Southeast Asia region, and it shows that the total Indonesian exports to countries in Southeast Asia each month amounted to US $\$ 3.48$ billion before the pandemic and dropped to US\$ 3.24 billion during the pandemic (a monthly average decrease of 29.20\%). Indonesian exports to the Southeast Asia region declined, except for Malaysia, Brunei, Myanmar, Vietnam and Timor-Leste. Meanwhile, its imports decreased by $21.34 \%$ (from US\$ 3.27 billion to US $\$ 2.57$ billion). The performance of Indonesia's imports from each of these countries in the Southeast Asia region have all decreased.

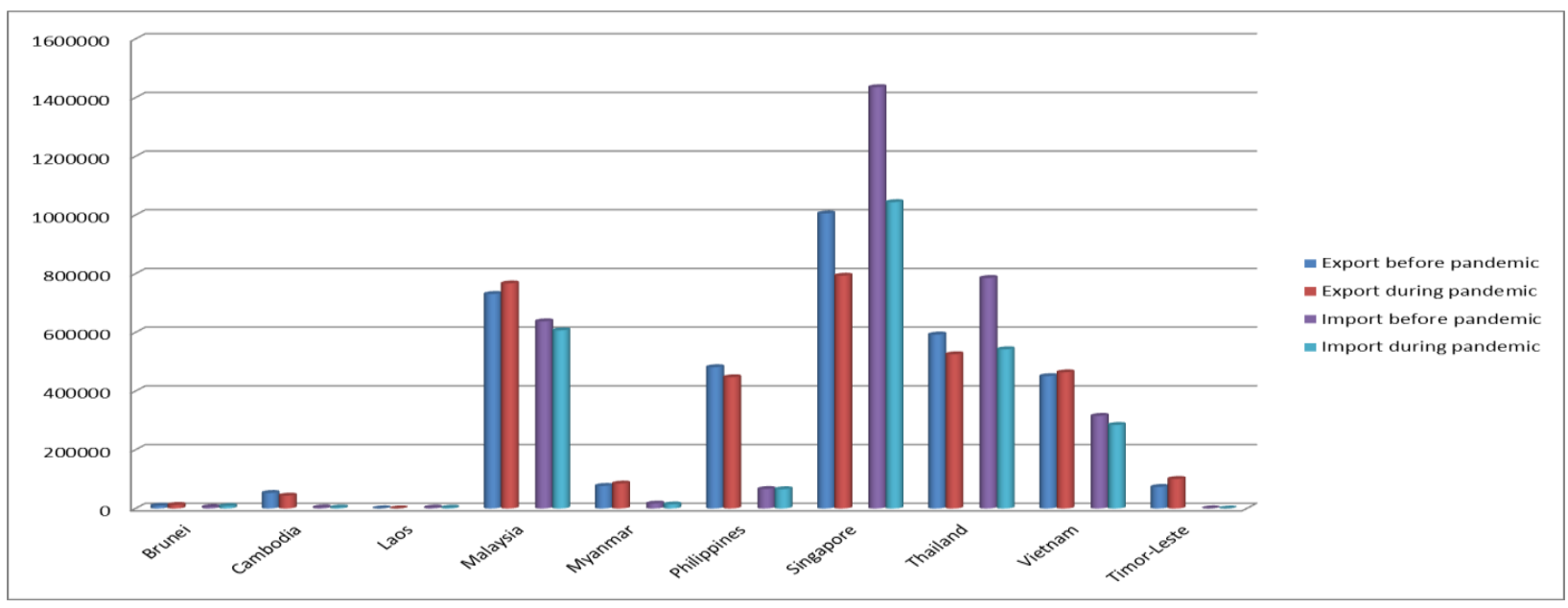

Figure 1. Indonesia's average exports and imports before and during Covid-19 in Southeast Asia (US\$ 1000).

\subsubsection{Indonesia's Exports and Imports in the East Asia Region}

Figure 2 illustrates Indonesia's export and import performance in the East Asia region, which are mainly to and from China, Japan, and South Korea. Indonesia's average exports to the East Asia region per month increased by $12.94 \%$ (from US $\$ 4.75$ billion before the pandemic to US $\$ 5.37$ billion during the pandemic). This increase was due to a rise in average exports to China by $34.07 \%$ (US $\$ 2.32$ billion to US\$ 3.10 billion), Taiwan by $16.35 \%$ (US $\$$ 0.33 billion to US $\$ 0.38$ billion), and North Korea by $2119.89 \%$ (US\$ 14.28 thousand to US $\$ 317.00$ thousand). Exports to other countries (Hong Kong, Macau, Japan, South Korea, and Mongolia) decreased, while Indonesia's imports from countries in the East Asia region decreased by $6.67 \%$ (from US\$ 6.11 billion before the pandemic to 
US $\$ 5.70$ billion during the pandemic). This decline was caused by falling imports from every country in this region except China, which increased by $3.08 \%$ (from US $\$ 3.56$ billion to US $\$ 3.67$ billion).

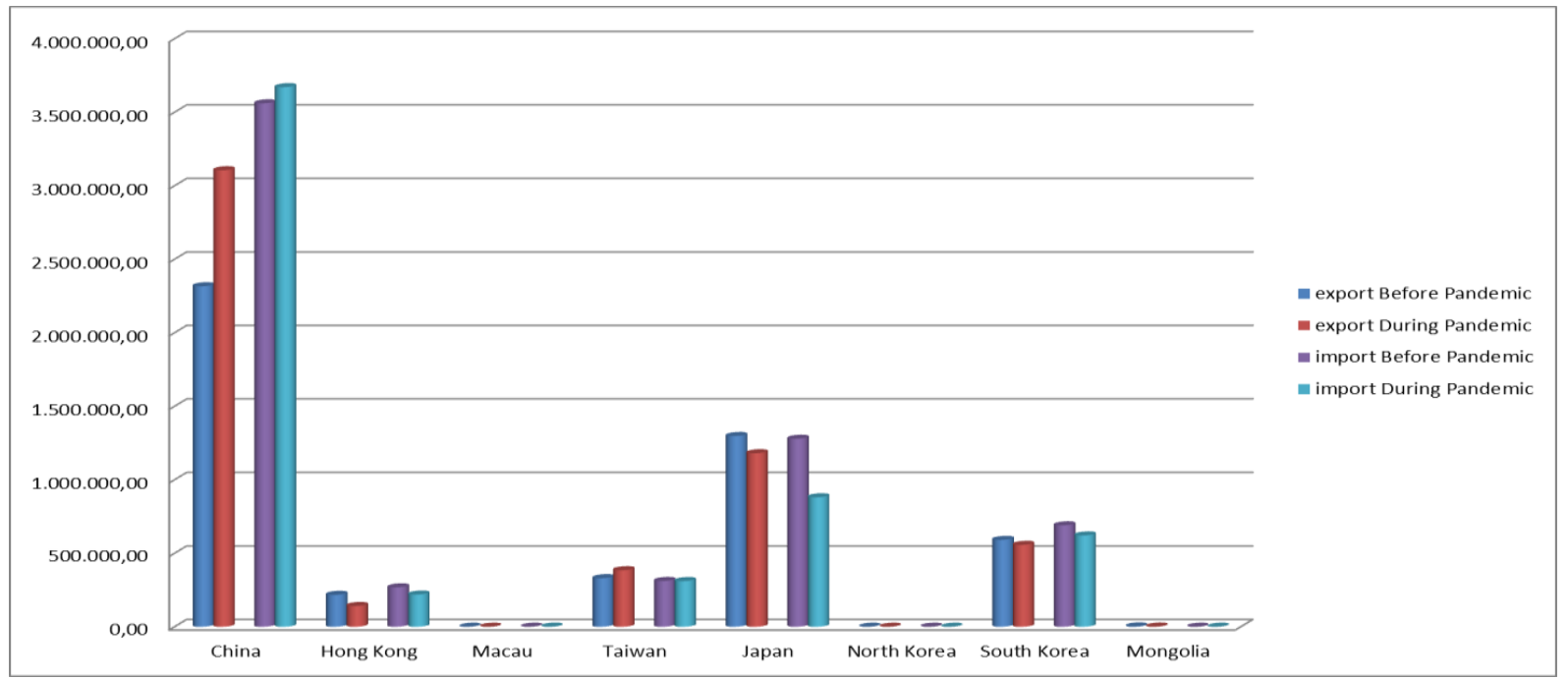

Figure 2. Indonesia's average exports and imports before and during Covid-19 in East Asia (US\$1000).

\subsubsection{Indonesia's Exports and Imports in the South Asia Region}

Figure 3 illustrates Indonesia's export and import performance in the South Asia region. Indonesia's average exports to the South Asian region decreased slightly by 3.09\% (from US $\$ 1.35$ billion to US $\$ 1.30$ billion). The majority of Indonesia's exports in this region is to India (more than 70\%), but Indonesia's exports to countries in the South Asian region have decreased (India, Bangladesh, Bhutan, Maldives and Nepal). On the other hand, Indonesia's exports to Mali, Pakistan, Sri Lanka and Afghanistan increased slightly. Exports to Pakistan increased by $41.49 \%$ (from US\$ 0.16 billion to US\$ 0.23 billion), export to Sri Lanka increased by $14.14 \%$ (from US $\$ 24.50$ million to US\$27.97 million), exports to Afghanistan increased by $23.03 \%$ (US\$ 1.38 million to US\$ 1.69 million), and exports to Mali increased by $26.05 \%$ (US\$ 0.51 million to US\$ 0.65 million). On the other hand, Indonesia's average imports from the South Asian region showed a decline of $17.53 \%$ (from US $\$ 529.88$ million to US\$ 437 million). Overall, Indonesia's imports from countries in the region decreased, except for India, which increased by $16.94 \%$ (from US\$ 350.99 million to US\$ 410.45 million).

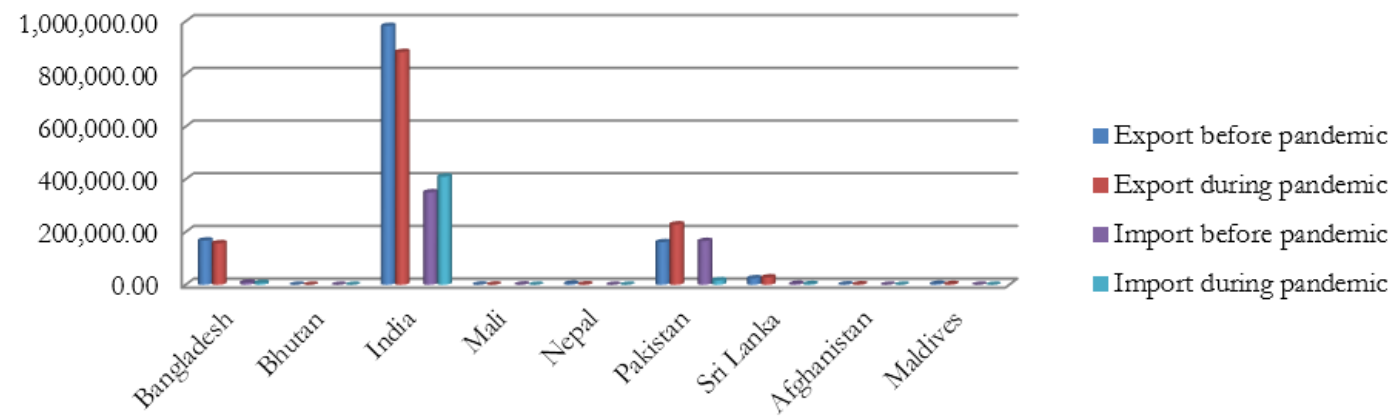

Figure 3. Indonesia's average exports and imports before and during Covid-19 in South Asia (US\$1000).

\subsubsection{Indonesia's Exports and Imports in the Central Asia Region}

Figure 4 illustrates Indonesia's export and import performance in the Central Asia region. Indonesia's exports to this region showed a decrease during the pandemic by $81.21 \%$ (from US $\$ 16.31$ million to US $\$ 1.43$ million). Indonesia's exports to this region all experienced a decline except Turkmenistan and Uzbekistan. Exports to Kazakhstan dropped drastically by $90.68 \%$ (from US $\$ 15.19$ million to US\$ 1.42 million), and exports to Tajikistan and Kyrgyzstan decreased slightly. Meanwhile, exports to Turkmenistan increased by $25.54 \%$ (from US $\$ 158.35$ 
thousand to US $\$ 198.80$ thousand), and exports to Uzbekistan increased by $71.68 \%$ (from US\$ 0.73 million to US $\$$ 1.25 million). Likewise, Indonesia's imports from this region increased by $45.07 \%$ (from US $\$ 12.69$ million to US $\$$ 18.41 million). Furthermore, Indonesia's imports from each country in this region decreased, except for Kazakhstan, which increased by $55.58 \%$ (from US\$ 10.94 million to US $\$ 17.01$ million).

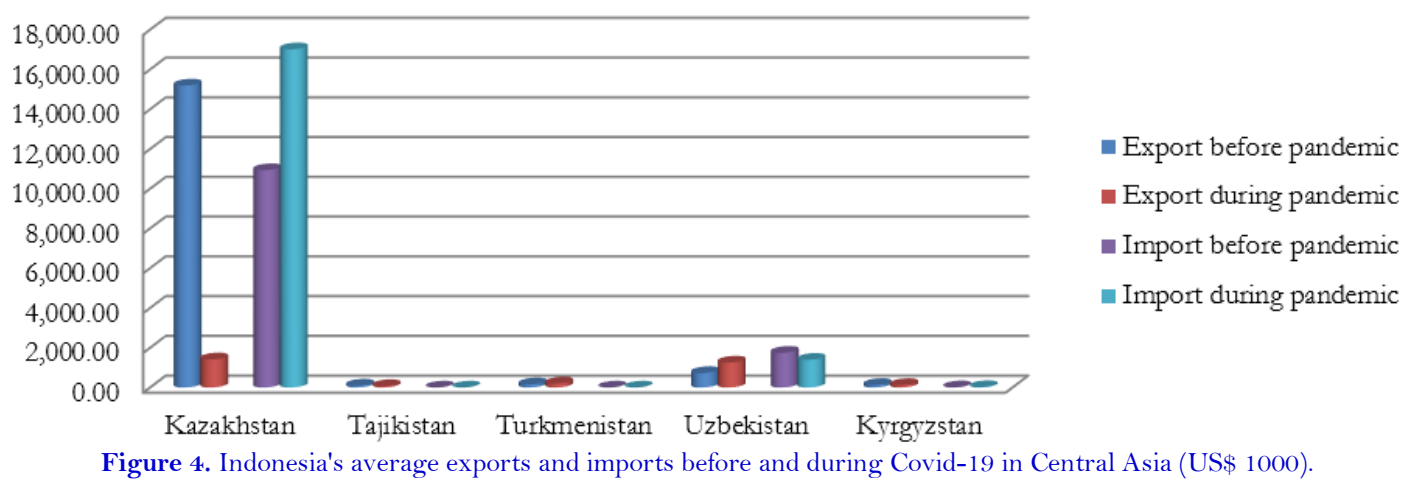

\subsubsection{Indonesia's Exports and Imports in the West Asia Region}

Figure 5 illustrates Indonesia's export and import performance in the West Asia region. Indonesia's exports and imports in this region are primarily to and from Saudi Arabia, the United Arab Emirates (UAE), and Turkey. Indonesia's average exports to the West Asia region per month decreased by $5.70 \%$ (from US $\$ 478.01$ million before the pandemic to US\$ 450.76 million during the pandemic). Exports to several countries in the West Asian region that experienced a decrease include Saudi Arabia, Bahrain, Kuwait, Oman, Qatar, the UAE, Palestine, Lebanon, Cyprus, Yemen, Syria, Armenia, and Azerbaijan. On the other hand, Indonesia's exports to Iraq, Israel, Turkey, Iran, Georgia and Jordan increased. Some of Indonesia's export destinations that experienced a high decline were Saudi Arabia, which fell 11.33\% (from US\$ 128.73 million to US\$114.15 million), the UAE decreased $10.53 \%$ (from US $\$ 123.95$ million to US $\$ 110.89$ million), Oman decreased by $41.23 \%$ (from US $\$ 23.83$ million to US\$ 14.00 million), Kuwait decreased by $25.86 \%$ (from US\$ 16.38 million to US\$ 12.14 million), Yemen decreased $18.17 \%$ (from US $\$ 12.61$ million to US $\$ 10.32$ million), Lebanon fell $27.49 \%$ (from US $\$ 6.08$ million to US $\$ 4.41$ million), Syria fell $37.62 \%$ (from US\$ 3.24 million to US\$ 2.02 million). Indonesia's average import from the West Asia region per month decreased by $21.11 \%$ (from US $\$ 696.37$ million before the pandemic to US $\$ 549.31$ million during the pandemic). Imports from several countries in the West Asian region that experienced a decrease include Saudi Arabia, Bahrain, Kuwait, Oman, Qatar, the UAE, Palestine, Lebanon, Turkey, Iran, Yemen, Georgia, and Jordan. On the other hand, Indonesia's imports from this region have increased, namely from Iraq, Israel, Cyprus, Syria, Armenia, and Azerbaijan.

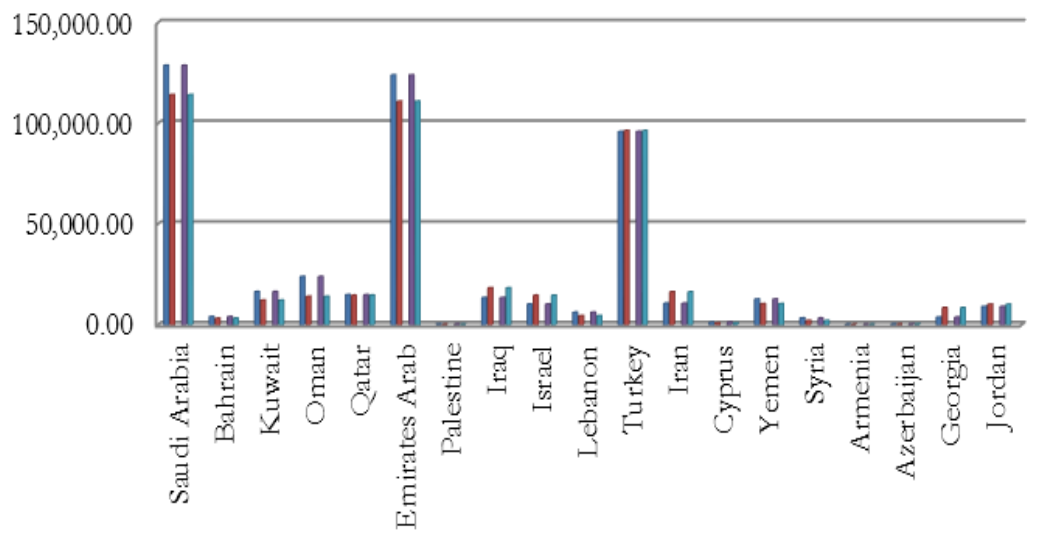

Export before pandemic

Export during pandemic

Import before pandemic

Import during pandemic

Figure 5. Indonesia's average exports and imports before and during Covid-19 in West Asia (US\$ 1000). 
Asian Economic and Financial Review, 2021, 11(11): 923-937

Table-1. Test results of export and import differences before and during the Covid-19 pandemic in Southeast Asia.

\begin{tabular}{|c|c|c|c|c|c|c|c|c|c|c|}
\hline \multirow{3}{*}{ Countries } & \multicolumn{5}{|c|}{ Export } & \multicolumn{5}{|c|}{ Import } \\
\hline & \multirow[t]{2}{*}{$\mathbf{t}$} & \multirow[t]{2}{*}{ df } & \multirow[t]{2}{*}{ Sig. (2-tailed) } & \multicolumn{2}{|c|}{$\begin{array}{l}\text { 90\% Confidence Interval of the } \\
\text { Difference }\end{array}$} & \multirow[t]{2}{*}{$\mathbf{t}$} & \multirow[t]{2}{*}{ df } & \multirow{2}{*}{$\begin{array}{c}\text { Sig. } \\
(2-\text { tailed })\end{array}$} & \multicolumn{2}{|c|}{$\begin{array}{c}90 \% \text { Confidence Interval of } \\
\text { the Difference }\end{array}$} \\
\hline & & & & Lower & Upper & & & & Lower & Upper \\
\hline Brunei & -2.645 & 26 & $0.014^{* * *}$ & -5606.22 & -703.20 & -1.106 & 26 & 0.279 & -9372.10 & 2813.62 \\
\hline Cambodia & 2.897 & 26 & $0.008 * * *$ & 2623.84 & 15446.50 & 0.789 & 26 & 0.437 & -463.67 & 1041.95 \\
\hline Laos & 1.738 & 26 & $0.094 *$ & -24.85 & 297.21 & 0.459 & 26 & 0.650 & -1310.89 & 2064.04 \\
\hline Malaysia & -0.654 & 26 & 0.519 & -148445.74 & 76804.44 & 0.658 & 26 & 0.516 & -65109.16 & 126464.40 \\
\hline Myanmar & -1.591 & 26 & 0.124 & -18451.63 & 2348.22 & 1.244 & 26 & 0.225 & -1836.49 & 7468.98 \\
\hline Philippines & 1,800 & 26 & $0,083^{*}$ & 5680,37 & 211249,36 & 0.078 & 26 & 0.939 & -20278.63 & 21873.64 \\
\hline Singapore & 2.814 & 26 & $0.009 * * *$ & 57135.41 & 366997.26 & 5.914 & 26 & $0.000^{* * * *}$ & 255632.51 & 528014.86 \\
\hline Thailand & 0.807 & 26 & 0.427 & -104183.41 & 238744.32 & 5.628 & 26 & $0.000^{*} * *$ & 154245.26 & 331734.08 \\
\hline Vietnam & -0.379 & 26 & 0.708 & -82915.04 & 57092.03 & 1.231 & 26 & 0.229 & -20655.74 & 82315.08 \\
\hline Timor-Leste & -0.401 & 26 & 0.691 & -166321.86 & 111970.09 & 2.798 & 26 & $0.010^{* * *}$ & 109.95 & 718.85 \\
\hline Southeast Asia & 1.339 & 26 & 0.192 & -126007.30 & 597420.36 & 4.322 & 26 & $0.000^{* * * *}$ & 365928.19 & 1029542.36 \\
\hline
\end{tabular}




\subsubsection{Difference Hypothesis Testing}

This section discusses the impact of the Covid-19 pandemic, which reduced Indonesia's export and import performance significantly. An independent sample t-test was used, and the limit of acceptance of the hypothesis is sig. $<10 \%$ or $\mathrm{t}>1.705$.

4.1.6. Test of the Differences Between Indonesia's Exports and Imports Before and During Covid-19 in the Southeast Asia Region

Indonesia's average exports per month to the Southeast Asian region was US $\$ 29.35$ billion before the pandemic and US $\$ 20.78$ billion during the pandemic, and its imports per month from the Southeast Asian region amounted to US $\$ 3.27$ billion before the pandemic and US $\$ 2.57$ billion during the pandemic.

Table 1 shows the impact of the pandemic on Indonesia's exports and imports in the Southeast Asian region. Exports to this region decreased significantly (t: $1.339<1.670$; sig. $0.192>0.10$ ). Indonesia's exports that experienced a significant decrease were to Singapore (t: $2.814>1.705$; sig. $0.009<0.10$ ), Cambodia (t: $2.897>$ 1.705; sig. $0.008<0.10$ ), Philippines (t: $1.800>1.705$; sig. $0.083<0.10$ ) and Laos (t: $1.738>1.705$; sig. $0.094<$ 0.10). On the other hand, exports to Brunei experienced a significant increase (t: $-2.645>1.705$; sig. $0.014<0.10)$. Meanwhile, exports to other countries in the region change insignificantly. Furthermore, the average import from Southeast Asia decreased significantly (t: $4.322>1.705$; sig. $0.000<0.10$ ). This is because imports from Singapore (t: $5.914>1.705$; sig. $0.000<0.10)$ and Thailand (t: $5.628>1.705$; sig. $0.000<0.10$ ) decreased significantly. While others decreased insignificantly.

\subsubsection{Test of the Differences Between Indonesia's Exports and Imports Before and During Covid-19 in the East Asia Region}

Indonesia's exports and imports to the East Asia region are quite large; the average export per month to the Southeast Asian region is US $\$ 4.75$ billion before the Covid-19 pandemic and US $\$ 5.37$ billion during the Covid-19 pandemic. On the other hand, Indonesia's imports per month from the Southeast Asian region amounted to US\$ 6.11 billion before the pandemic and US $\$ 5.70$ billion during the pandemic. Table 2 shows the impact of the pandemic on Indonesia's exports and imports in the East Asia region. Indonesia's average exports to this region actually increased significantly (t: $-2.604>1.705$; sig. $0.015<0.10$ ), which was due to an increase to China (t: $4.516>1.705$; sig. $0.000<0.10)$ and Taiwan $(\mathrm{t}:-1.857>1.705$; sig. $0.075<0.10)$. Meanwhile, exports to Hong Kong, Macau and Japan decreased significantly, and exports to North Korea, South Korea and Mongolia declined insignificantly. On the other hand, the impact of the pandemic on Indonesia's average imports in the East Asia region decreased insignificantly ( $\mathrm{t}: 1.175<1.705$; sig. $0.250>0.10$ ). The countries of origin of Indonesia's imports that decreased significantly were Hong Kong, Macau and Japan, while others decreased insignificantly.

\subsubsection{Test of the Differences Between Indonesia's Exports and Imports Before and During Covid-19 in the South Asia Region}

Indonesia's average exports per month to this region were US $\$ 1.35$ billion before the pandemic and US $\$ 1.30$ billion during the pandemic, while Indonesia's average imports from this region was US $\$ 529.88$ million before the pandemic and US $\$ 437.00$ million during the pandemic. Table 3 shows that Indonesia's exports to the South Asia region decreased insignificantly ( $\mathrm{t}$ : $0.366<1.705$; sig. 0.694 > 0.10). Indonesia's exports to Pakistan increased significantly (t: $-3.008<1.705$; sig. $0.006<0.10)$ and decreased significantly to the Maldives (t: $3.125<1.705$; sig. $0.004<0.10$ ), while the others decreased insignificantly. In terms of imports, imports from this region decreased insignificantly (t: -0.641 < 1.670; sig. $0.527>0.10$ ). Furthermore, imports from Bangladesh, Bhutan, Mali, and Sri Lanka showed a significant decline, imports from India, Nepal, Pakistan, and Afghanistan decreased insignificantly, while imports from the Maldives increased significantly. 
Asian Economic and Financial Review, 2021, 11(11): 923-937

Table-2. Test results of export and import differences before and during the Covid-19 pandemic in East Asia.

\begin{tabular}{|c|c|c|c|c|c|c|c|c|c|c|}
\hline \multirow{3}{*}{ Countries } & \multicolumn{5}{|c|}{ Export } & \multicolumn{5}{|c|}{ Import } \\
\hline & \multirow[t]{2}{*}{$\mathrm{t}$} & \multirow[t]{2}{*}{ df } & \multirow{2}{*}{$\begin{array}{c}\text { Sig. } \\
(2-\text { tailed })\end{array}$} & \multicolumn{2}{|c|}{$\begin{array}{c}90 \% \text { Confidence Interval of } \\
\text { the Difference }\end{array}$} & \multirow[t]{2}{*}{$\mathrm{t}$} & \multirow[t]{2}{*}{ df } & \multirow{2}{*}{$\begin{array}{c}\text { Sig. } \\
(2-\text { tailed })\end{array}$} & \multicolumn{2}{|c|}{$\begin{array}{l}\text { 90\% Confidence Interval of the } \\
\text { Difference }\end{array}$} \\
\hline & & & & Lower & Upper & & & & Lower & Upper \\
\hline China & -4.516 & 26 & 0.000**** & -1148177.41 & -429945.12 & -0.450 & 26 & 0.657 & -610429.87 & 391307.77 \\
\hline Hong Kong & 3.900 & 26 & $0.001 * * *$ & 35864.32 & 115793.94 & 2.353 & 26 & $0.026^{* *}$ & 6165.64 & 91411.31 \\
\hline Macau & 4.782 & 26 & $0.000 * * *$ & 134.17 & 336.48 & -2.687 & 26 & $0.012^{*} *$ & -583.80 & -77.72 \\
\hline Taiwan & -1.857 & 26 & $0.075^{*}$ & -113792.60 & 5767.49 & 0.035 & 26 & 0.972 & -46050.45 & 47663.26 \\
\hline Japan & 2.455 & 26 & $0.021 * *$ & 19068.26 & 215475.91 & 5.543 & 26 & $0.000^{* * * *}$ & 250414.95 & 545584.06 \\
\hline North Korea & 1.467 & 26 & 0.154 & -2.32 & 30.77 & 1.152 & 26 & 0.260 & -93.13 & 480.64 \\
\hline South Korea & 1.235 & 26 & 0.228 & -22338.43 & 89588.35 & 1.397 & 26 & 0.174 & -32558.06 & 170666.27 \\
\hline Mongolia & 0.986 & 26 & 0.333 & -970.81 & 2761.43 & 0.766 & 26 & 0.451 & -466.44 & 1020.19 \\
\hline East Asia & -2.604 & 26 & 0.015** & -1018650.01 & -212389.47 & 1.175 & 26 & 0.250 & -183668.93 & 998126.49 \\
\hline
\end{tabular}

Note : * significant at $10 \%$, ** significant at $5 \%$, *** significant at $1 \%$

Table-3. Test results of export and import differences before and during the Covid-19 pandemic in South Asia.

\begin{tabular}{|c|c|c|c|c|c|c|c|c|c|c|}
\hline \multirow{3}{*}{ Countries } & \multicolumn{5}{|c|}{ Export } & \multicolumn{5}{|c|}{ Import } \\
\hline & \multirow[t]{2}{*}{ t } & \multirow[t]{2}{*}{ df } & \multirow[t]{2}{*}{ Sig. (2-tailed) } & \multicolumn{2}{|c|}{$\begin{array}{l}\text { 90\% Confidence Interval of the } \\
\text { Difference }\end{array}$} & \multirow[t]{2}{*}{$\mathbf{t}$} & \multirow[t]{2}{*}{ df } & \multirow{2}{*}{$\begin{array}{c}\text { Sig. } \\
(2-\text { tailed })\end{array}$} & \multicolumn{2}{|c|}{$\begin{array}{l}\text { 90\% Confidence Interval of the } \\
\text { Difference }\end{array}$} \\
\hline & & & & Lower & Upper & & & & Lower & Upper \\
\hline$\overline{\text { Bangladesh }}$ & 0.433 & 26 & 0.669 & -38771.20 & 59461.45 & 2.046 & 26 & $0.051^{*}$ & -8.26 & $\frac{11}{3529.41}$ \\
\hline Bhutan & 0.571 & 26 & 0.573 & -87.80 & 155.33 & 1.787 & 26 & $0.086^{*}$ & -0.07 & 0.96 \\
\hline India & 1.448 & 26 & 0.160 & -41556.90 & 239512.03 & -1.184 & 26 & 0.247 & -162621.34 & 43720.84 \\
\hline Mali & -0.852 & 26 & 0.402 & -455.46 & 188.60 & 2.420 & 26 & $0.023^{*} *$ & 109.46 & 1343.13 \\
\hline Nepal & 1.140 & 26 & 0.265 & -2028.83 & 7082.34 & -0.319 & 26 & 0.752 & -10.46 & 7.16 \\
\hline Pakistan & -3.008 & 26 & $0.006^{* * * *}$ & -113007.15 & -21265.04 & 1.104 & 26 & 0.280 & -81182.32 & 379321.83 \\
\hline Sri Lanka & -0.920 & 26 & 0.366 & -11206.68 & 4276.13 & 2.519 & 26 & $0.018^{* *}$ & 152.97 & 1510.10 \\
\hline Afghanistan & -1.336 & 26 & 0.193 & -804.69 & 170.62 & -0.835 & 26 & 0.411 & -34.45 & 14.54 \\
\hline Maldives & 3.125 & 26 & $0.004 * * * *$ & 271.61 & 1315.64 & -2.038 & 26 & $0.052^{*}$ & -67.71 & 0.29 \\
\hline South Asia & 0.398 & 26 & 0.694 & -173323.18 & 256573.20 & 0.641 & 26 & 0.527 & -154223.30 & 340008.39 \\
\hline
\end{tabular}


4.1.9. Test of the Difference Between Indonesia's Exports and Imports Before and During Covid-19 in the Central Asia Region.

Indonesia's exports and imports in the Central Asia region is not large, only US $\$ 16.31$ million before and US\$ 1.43 million during the pandemic for exports, and US\$ 12.69 million before and US $\$ 18.41$ million after the pandemic for imports. However, the changes due to the pandemic show a significant decline (t: 2.336 > 1705 ; sig. $0.027<0.10)$. If traced further (see Table 4), this decline was due to a significant decline in exports to Kazakhstan (t: $2.426>1.705$; sig. $0.023<0.10)$ and an insignificant decline to Tajikistan and Kyrgyzstan. On the other hand, exports to Turkmenistan and Uzbekistan increased insignificantly. Meanwhile, imports from this region increased insignificantly (t: $-1.046<1.705$; sig. $0.305>0.10$ ). Imports from Tajikistan, Turkmenistan, Uzbekistan decreased insignificantly, while imports from Kazakhstan and Kyrgyzstan increased insignificantly.

Table-4. Test results of export and import differences before and during the Covid-19 pandemic in Central Asia.

\begin{tabular}{|c|c|c|c|c|c|c|c|c|c|c|}
\hline \multirow{3}{*}{ Countries } & \multicolumn{5}{|c|}{ Export } & \multicolumn{5}{|c|}{ Import } \\
\hline & \multirow[t]{2}{*}{$\mathbf{t}$} & \multirow[t]{2}{*}{ df } & \multirow[t]{2}{*}{$\begin{array}{c}\text { Sig. } \\
(2- \\
\text { tailed })\end{array}$} & \multicolumn{2}{|c|}{$\begin{array}{c}90 \% \text { Confidence } \\
\text { Interval of the } \\
\text { Difference }\end{array}$} & \multirow[t]{2}{*}{$\mathbf{t}$} & \multirow[t]{2}{*}{ df } & \multirow[t]{2}{*}{$\begin{array}{c}\text { Sig. } \\
(2- \\
\text { tailed) } \\
\end{array}$} & \multicolumn{2}{|c|}{$\begin{array}{c}90 \% \text { Confidence } \\
\text { Interval of the } \\
\text { Difference }\end{array}$} \\
\hline & & & & Lower & Upper & & & & Lower & Upper \\
\hline Kazakhstan & 2.426 & 26 & $0.023 * *$ & 2103.89 & 25450.88 & -1.099 & 26 & 0.282 & -17448.58 & 5291.59 \\
\hline Tajikistan & 0.591 & 26 & 0.559 & -67.38 & 121.81 & 0.999 & 26 & 0.327 & -1.27 & 4.86 \\
\hline Turkmenistan & -.819 & 26 & 0.420 & -124.69 & 43.80 & 0.948 & 26 & 0.352 & -4.55 & 12.34 \\
\hline Uzbekistan & -2.149 & 26 & 0.041 & -1025.03 & -22.77 & 1.160 & 26 & 0.256 & -272.80 & 980.18 \\
\hline Kyrgyzstan & 0.061 & 26 & 0.952 & -123.90 & 131.50 & -0.838 & 26 & 0.410 & -29.04 & 12.22 \\
\hline Central Asia & 2.336 & 26 & $0.027 * *$ & 3575.05 & 22913.06 & -1.046 & 26 & 0.305 & -15062.46 & 3607.40 \\
\hline
\end{tabular}

\subsubsection{Test of the Differences between Indonesia's Exports and Imports Before and During Covid-19 in the West Asia Region}

Indonesia's exports and imports in the West Asia region are quite large, US $\$ 478.01$ million before and US $\$$ 450.76 million during the pandemic for exports, and US\$ 696.37 million before and US $\$ 549.31$ million after the pandemic for imports. Table 5 shows the results of the assessment of Indonesia's export and import differences in this region. Exports to this region decreased insignificantly (t: $1.073<1.670$; sig. $0.293>0.10$ ). Exports to Saudi Arabia, Bahrain, Kuwait, Oman, the UAE, Palestine, Lebanon, Syria, and Armenia decreased significantly. Meanwhile, exports to Qatar, Cyprus, Yemen, and Azerbaijan decreased insignificantly. On the other hand, exports to Iraq, Israel, Iran, and Georgia increased significantly, while exports to Turkey and Jordan increased insignificantly. On the import side, there was a significant decline in imports from this region (t: $3.243>1.670$; sig. 0.003 < 0.10). Imports from Saudi Arabia, Bahrain, and Qatar decreased significantly, while imports from Kuwait, Oman, the UAE, Palestine, Lebanon, Turkey, Iran, Georgia, and Jordan decreased insignificantly. Meanwhile, imports from Armenia increased significantly, and imports from Iraq, Israel, Cyprus, Yemen, Syria, and Azerbaijan increased insignificantly.

\subsubsection{The Main Export and Import Destination Countries in Asia}

The ten main export destinations for Indonesia are China, Japan, Singapore, India, Malaysia, the Philippines, South Korea, Vietnam, Thailand, and Taiwan. Five of the ten export destination countries are in the ASEAN region. Based on data from the Central Bureau of Statistics (BPS), Indonesia's exports to these ten countries made up $61.99 \%$ of Indonesia's total exports, and $88.20 \%$ of Indonesia's total exports to Asia. Indonesia's exports to four countries increased (China, Malaysia, Vietnam, and Taiwan), while exports to Singapore and Japan decreased significantly, and exports to South Korea, India, Philippines, and Thailand decreased insignificantly. China is the primary export contributor (19.48\%), followed by Japan, Singapore, India, Malaysia, South Korea, Philippines, Thailand, Vietnam, and Taiwan (8.37\%, 6.53\%, 6.37\%, 4.96\%, 3.99\%, 3.62\%, 3.13\%, 3.03\%, and 2.51\%, respectively). Table 6 shows the five main products that Indonesia exports to each of these countries. 
Table-5. Test results of export and import differences before and during the Covid-19 pandemic in West Asia.

\begin{tabular}{|c|c|c|c|c|c|c|c|c|c|c|}
\hline \multirow{3}{*}{ Countries } & \multicolumn{5}{|c|}{ Export } & \multicolumn{5}{|c|}{ Import } \\
\hline & \multirow[t]{2}{*}{$\mathbf{t}$} & \multirow[t]{2}{*}{ df } & \multirow[t]{2}{*}{$\begin{array}{c}\text { Sig. } \\
(2-\text { tailed })\end{array}$} & \multicolumn{2}{|c|}{$\begin{array}{l}90 \% \text { Confidence Interval } \\
\text { of the Difference }\end{array}$} & \multirow[t]{2}{*}{$\mathbf{t}$} & \multirow[t]{2}{*}{ df } & \multirow[t]{2}{*}{$\begin{array}{c}\text { Sig. } \\
(2-\text { tailed })\end{array}$} & \multicolumn{2}{|c|}{$\begin{array}{c}90 \% \\
\text { Confidence } \\
\text { Interval of } \\
\text { the Difference }\end{array}$} \\
\hline & & & & Lower & Upper & & & & Lower & Upper \\
\hline Saudi Arabia & 1.950 & 26 & $0.062^{*}$ & -788.29 & 29951.48 & 2.779 & 26 & $0.010^{* * *}$ & 20050.96 & 134005.81 \\
\hline Bahrain & 2.178 & 26 & $0.039^{* *}$ & 43.14 & 1487.77 & 1.850 & 26 & $0.076^{*}$ & -1104.80 & 20971.09 \\
\hline Qatar & 0.044 & 26 & 0.965 & -9883.88 & 10313.24 & 3.970 & 26 & $0.001^{* * *} *$ & 13489.01 & 42451.93 \\
\hline UAE & 1.899 & 26 & $0.069^{*}$ & -1077.66 & 27185.71 & 1.486 & 26 & 0.149 & -10952.29 & 68111.37 \\
\hline Palestine & 2.194 & 26 & 0.037 ** & 9.35 & 286.39 & 1.060 & 26 & 0.299 & -59.09 & 184.87 \\
\hline Iraq & -1.929 & 26 & $0.065^{*}$ & -10050.53 & 319.87 & -1.007 & 26 & 0.323 & -5238.96 & 1793.01 \\
\hline Israel & -3.344 & 26 & $0.003 * * *$ & -7054.17 & -1682.90 & -1.121 & 26 & 0.272 & -6464.29 & 1900.71 \\
\hline Syria & 2.985 & 26 & $0.006 * * *$ & 379.57 & 2059.24 & -1.542 & 26 & 0.135 & -42.82 & 6.11 \\
\hline Armenia & 2.014 & 26 & $0.054^{*}$ & -1.87 & 185.13 & -2.624 & 26 & $0.014 * *$ & -118.38 & -14.38 \\
\hline Azerbaijan & 0.451 & 26 & 0.656 & -123.19 & 192.47 & -1.008 & 26 & 0.323 & -13309.72 & 4548.90 \\
\hline Georgia & -1.753 & 26 & $0.091 *$ & -10269.26 & 814.45 & 0.328 & 26 & 0.746 & -676.13 & 932.63 \\
\hline Jordan & -0.978 & 26 & 0.337 & -3500.62 & 1243.71 & 0.422 & 26 & 0.677 & -4058.91 & 6153.32 \\
\hline West Asia & 1.073 & 26 & 0.293 & -24948.09 & 79459.83 & 3.243 & 26 & $0.003 * * *$ & 69707.95307 & 224393.38122 \\
\hline
\end{tabular}

Table-6. Indonesia's main exported products to ten countries in Asia

\begin{tabular}{|c|c|c|c|c|c|c|c|c|c|c|}
\hline Products & China & Japan & Singapore & India & Malaysia & South Korea & Philippines & Thailand & Vietnam & Taiwan \\
\hline Mineral fuels, mineral oils and their refined products & $\sqrt{ }$ & $\sqrt{ }$ & $\sqrt{ }$ & $\sqrt{ }$ & $\sqrt{ }$ & $\sqrt{ }$ & $\sqrt{ }$ & $\sqrt{ }$ & $\sqrt{ }$ & $\sqrt{ }$ \\
\hline $\begin{array}{l}\text { Animal or vegetable fats and oils and their } \\
\text { dissociated products }\end{array}$ & $\sqrt{ }$ & & $\sqrt{ }$ & $\sqrt{ }$ & $\sqrt{ }$ & $\sqrt{ }$ & $\sqrt{ }$ & & $\sqrt{ }$ & \\
\hline Iron and steel & $\sqrt{ }$ & & & $\sqrt{ }$ & $\sqrt{ }$ & $\sqrt{ }$ & & & $\sqrt{ }$ & $\sqrt{ }$ \\
\hline Metal ore, slag and ash & $\sqrt{ }$ & $\sqrt{ }$ & & $\sqrt{ }$ & & $\sqrt{ }$ & & & & \\
\hline Electrical machinery and equipment and their parts & & & $\sqrt{ }$ & & & $\sqrt{ }$ & & $\sqrt{ }$ & $\sqrt{ }$ & \\
\hline Vehicles other than those moving on railroad tracks, & & & & & $\sqrt{ }$ & & $\sqrt{ }$ & $\sqrt{ }$ & $\sqrt{ }$ & \\
\hline
\end{tabular}




\begin{tabular}{|c|c|c|c|c|c|c|c|c|}
\hline and their parts and accessories & & & & & & & & \\
\hline Pulp of wood or of other fibrous cellulosic materials & $\sqrt{ }$ & $\sqrt{ }$ & & & & & & \\
\hline Various chemical products & & & & $\sqrt{ }$ & $\sqrt{ }$ & & & \\
\hline Paper, paperboard and articles of paper pulp & & & & & & $\sqrt{ }$ & & $\sqrt{ }$ \\
\hline $\begin{array}{l}\text { Nuclear reactors, boilers, machines and mechanical } \\
\text { equipment, and their components }\end{array}$ & & & $\sqrt{ }$ & & & & $\sqrt{ }$ & \\
\hline Rubber and articles thereof & & $\sqrt{ }$ & & & & & & \\
\hline Wood and wooden goods & & $\sqrt{ }$ & & & & & & $\sqrt{ }$ \\
\hline $\begin{array}{l}\text { Natural pearls, cultured pearls, precious or semi- } \\
\text { precious stones, precious metals }\end{array}$ & & & $\sqrt{ }$ & & & & & \\
\hline A variety of edible preparations & & & & & & $\sqrt{ }$ & & \\
\hline Copper and articles thereof & & & & & & & $\sqrt{ }$ & \\
\hline $\begin{array}{l}\text { Fish and crustaceans, mollusks and other aquatic } \\
\text { invertebrates }\end{array}$ & & & & & & & & $\sqrt{ }$ \\
\hline
\end{tabular}

Table-7. Indonesia's main imported products from ten countries in Asia.

\begin{tabular}{|c|c|c|c|c|c|c|c|c|c|c|}
\hline Products & China & Singapore & Japan & Malaysia & South Korea & Thailand & India & Taiwan & Vietnam & Hong Kong \\
\hline $\begin{array}{l}\text { Nuclear reactors, boilers, machines and mechanical } \\
\text { equipment; part of it }\end{array}$ & $\sqrt{ }$ & $\sqrt{ }$ & $\sqrt{ }$ & $\sqrt{ }$ & $\sqrt{ }$ & $\sqrt{ }$ & $\sqrt{ }$ & $\sqrt{ }$ & $\sqrt{ }$ & $\sqrt{ }$ \\
\hline Electrical machinery and equipment and their parts & $\sqrt{ }$ & $\sqrt{ }$ & & $\sqrt{ }$ & $\sqrt{ }$ & $\sqrt{ }$ & & $\sqrt{ }$ & $\sqrt{ }$ & $\sqrt{ }$ \\
\hline Iron and steel & $\sqrt{ }$ & & $\sqrt{ }$ & & $\sqrt{ }$ & & $\sqrt{ }$ & $\sqrt{ }$ & $\sqrt{ }$ & $\sqrt{ }$ \\
\hline Plastics and articles thereof & $\sqrt{ }$ & $\sqrt{ }$ & $\sqrt{ }$ & $\sqrt{ }$ & $\sqrt{ }$ & $\sqrt{ }$ & & $\sqrt{ }$ & & \\
\hline $\begin{array}{lllll}\begin{array}{l}\text { Inorganic } \\
\text { compounds }\end{array} & \text { chemicals; } & \text { organic } & \text { or inorganic } \\
\end{array}$ & $\sqrt{ }$ & $\sqrt{ }$ & & $\sqrt{ }$ & & & $\sqrt{ }$ & & & \\
\hline $\begin{array}{l}\text { Mineral fuels, mineral oils and their refined } \\
\text { products }\end{array}$ & & $\sqrt{ }$ & & $\sqrt{ }$ & $\sqrt{ }$ & & & & & \\
\hline $\begin{array}{l}\text { Vehicles other than those moving on railroad tracks, } \\
\text { and their parts and accessories }\end{array}$ & & & $\sqrt{ }$ & & & $\sqrt{ }$ & & & & \\
\hline Meat and edible meat scraps & & & & & & & $\sqrt{ }$ & $\sqrt{ }$ & & \\
\hline Knitted fabric or crocheted fabric & & & & & & & & & $\sqrt{ }$ & $\sqrt{ }$ \\
\hline $\begin{array}{l}\text { Seeds and fruit containing oil; seeds and fruit; } \\
\text { industrial plants or medicinal plants }\end{array}$ & & & & & & & $\sqrt{ }$ & & & \\
\hline Sugar and confectionery & & & & & & $\sqrt{ }$ & & & & \\
\hline Items of iron or steel & & & $\sqrt{ }$ & & & & & & & \\
\hline Footwear, gaiters; parts of the items & & & & & & & & & $\sqrt{ }$ & \\
\hline $\begin{array}{l}\text { Natural pearls, cultured pearls, precious or semi- } \\
\text { precious stones, precious metals }\end{array}$ & & & & & & & & & & $\sqrt{ }$ \\
\hline
\end{tabular}


In terms of imports, ten countries (China, Singapore, Japan, Malaysia, South Korea, Thailand, India, Taiwan, Vietnam, and Hong Kong) made up $66.58 \%$ of Indonesia's imports and 90.54\% of Asia's overall imports. Imports from Japan, Singapore, Thailand, and Hong Kong decreased significantly; imports from Malaysia, South Korea, Vietnam, and Taiwan decreased insignificantly; while imports from China and India increased. The most imports came from China (28.04\%), followed by Singapore (8.74\%), Japan (7.54\%), Malaysia (4.91\%), South Korea (4.85\%), Thailand (4.59\%), India (2.67\%), Taiwan (2.53\%), Vietnam (2.22\%), and Hong Kong (1.94\%). Table 7 shows the five main products imported from these ten countries.

\section{CONCLUSION}

The effects of the Covid-19 pandemic do not always reduce the exports and imports between countries. Of the 51 export destination countries for Indonesia in the Asian region, exports to 18 countries (35.29\%) decreased significantly, exports to 14 countries $(27.45 \%)$ decreased insignificantly, and exports to 19 countries (37.25\%) increased. When viewed from the ten primary export destination countries for Indonesia, exports to two countries (Singapore and Japan) decreased significantly, export to four countries (South Korea, India, the Philippines and Thailand) decreased significantly, and exports to four countries (China, Malaysia, Vietnam, and Taiwan) increased. On the import side, from the 51 countries of origin, Indonesia's imports from 11 countries (21.57\%) in the Asian region decreased significantly, imports from 24 countries $(47.05 \%)$ decreased insignificantly, and imports from 19 countries $(31.37 \%)$ increased. The majority of imported goods include nuclear reactors, boilers, mechanical machinery and equipment, electrical machinery and equipment, iron and steel, and plastics.

The spread of Covid-19 has brought both threats and opportunities. Therefore, the government, the private sector, and various other parties involved must implement policies that will save and control Indonesia's exports and imports. These policies should comprise fiscal stimulus, diversification of trading partners, deregulation, and the downstream industry related to export, among others. Exports to Japan and Singapore need to be increased in addition to building relations with other countries to reduce the risk of dependence on a small number of countries and expand Indonesia's economic opportunities. Further research is recommended to examine how the effects of the Covid-19 pandemic affected exports and imports of each type of product, and how the influence of the severity of the Covid-19 pandemic in a particular country affected export and import activities.

Funding: This study received no specific financial support.

Competing Interests: The authors declare that they have no competing interests.

Acknowledgement: Both authors contributed equally to the conception and design of the study.

\section{REFERENCES}

ADB. (2020a). Asian development bank outlook 2020: What drives innovation in Asia, special topic: The impact of the coronavirus outbreak-an update. Mandaluyong City, 1550 Metro Manila, Philippines: Asian Development Bank.

ADB. (2020b). Lockdown, loosening, and Asia's growth prospects: Asian development outlook supplement (pp. 1-12). Mandaluyong City, 1550 Metro Manila, Philippines: Asian Development Bank.

Ahmed, G., Gasaymeh, A. A., \& Mehmood, T. (2017). The global financial crisis and international trade. Asian Economic and Financial Review, 7(6), 600-610. Available at: https://doi.org/10.18488/journal.aefr.2017.76.600.610.

Ahn, B. J., Amiti, M., \& Weinstein, D. E. (2011). Trade finance and the great trade collapse. American Economic Review, 101(3), 298-302. Available at: https://doi.org/10.1257/aer.101.3.298.

Apergis, N., \& Apergis, E. (2020). The role of covid-19 for Chinese stock returns: Evidence from a GARCHX model. Asia-Pacific Journal of Accounting and Economics, 1-9. Available at: https://doi.org/10.1080/16081625.2020.1816185.

Baldwin, R. (2009). The great trade collapse: Causes, consequences and prospects. London UK: Centre for Economic Policy Research (CEPR). 
Baldwin, R., \& Tomiura, E. (2020). 5 thinking ahead about the trade impact of Covid-19. Economics in the Time of Covid-19, 59-71. Barua, S. (2020). Covid-19 pandemic and world trade: Some analytical notes. Germany: University Library of Munich.

Chor, D., \& Manova, K. (2012). Off the cliff and back? Credit conditions and international trade during the global financial crisis. Journal of International Economics, 87(1), 117-133. Available at: https://doi.org/10.1016/j.jinteco.2011.04.001.

Eaton, J., Kortum, S., Neiman, B., \& Romalis, J. (2011). Trade and the global recession. NBER Working Paper, No w 16666, at SSRN: https://papers.ssrn.com/sol3/papers.cfm?abstract_id=1737214.

ECLAC. (2020). Covid-19 Addressing the growing impact of Covid-19 with a view to reactivation with equality: New projections, Economic Commission for Latin America and the Caribbean (ECLAC), Special Report Covid-19, Santiago, July, 2020. Retrieved from: https://digitallibrary.un.org/record/3872898.

Evenett, S. J. (2020). Sicken thy neighbour: The initial trade policy response to Covid-19. The World Economy, 43(4), 828-839. Available at: https://doi.org/https://doi.org/10.1111/twec.12954.

Feenstra, R. (2003). Advanced international trade: Theory and evidence (2nd ed.). Princeton: Princeton University Press.

Fugazza, M. (2020). Impact of the Covid-19 pandemic on commodities exports to China. UNCTAD Research Paper No. 44.

Haroon, O., \& Rizvi, S. A. R. (2020). Covid-19: Media coverage and financial markets behavior-A sectoral inquiry. Journal of Behavioral and Experimental Finance, 27, 100343. Available at: https://doi.org/10.1016/j.jbef.2020.100343.

IMF. (2020). World economic outlook: The great lockdown. Washington, DC: International Monetary Fund.

Jackson, J., Weiss, M., Schwarzenberg, A., \& Nelson, R. (2021). Global economic effects of Covid-19: Congressional Research Service. (20) Retrieved from: https://crsreports.congress.gov.

Kaneda, M., Kubota, S., \& Tanaka, S. (2021). Who spent their Covid-19 stimulus payment? Evidence from personal finance software in Japan. The Japanese Economic Review, 72(3), 409-437. Available at: https://doi.org/10.1007/s42973-02 100080-0.

Maliszewska, M., Mattoo, A., \& van der Mensbrugghe, D. (2020). The potential impact of Covid-19 on GDP and trade: A preliminary assessment. Policy Research Working Paper. Retrieved from: https://doi.org/10.1596/1813-9450-9211.

McConnell, C., Brue, S., \& Flynn, S. (2009). Economics-princples, problems, and policies (18th ed.). New York: McGraw-Hill Companies, Inc.

Millath, M. A., \& Thowseaf, S. (2016). Export performance of special economic zones in India and its economic contribution. International Journal of Innovative Research in Management Studies, 1(10), 24-28.

Narayan, P. K. (2020). Has Covid-19 changed exchange rate resistance to shocks? Asian Economics Letters, 1, 3-6. Available at: https://doi.org/10.46557/001c.17389.

OECD. (2020). Coronavirus: The world economy at risk: OECD Interim Economic Assessment. 2 March. 2020. Organization for Economic Cooperation and Development. 1-15. Retrieved from: https://www.google.com/search?client=firefox-b$\underline{\mathrm{d} \& \mathrm{q}=\text { Coronavirus } \% 13 \mathrm{~A}+\text { The }+ \text { world }+ \text { economy }+ \text { at }+ \text { risk. }+ \text { OECD }+ \text { Interim }+ \text { Economic }+ \text { Assessment } \% 12 \mathrm{C}+\% 2820+\mathrm{M}}$ $\underline{\operatorname{arch} \% 2829 .}$.

Phan, D. H. B., \& Narayan, P. K. (2020). Country responses and the reaction of the stock market to Covid-19-a preliminary exposition. Emerging Markets Finance and Trade, 56(10), 2138-2150. Available at: https://doi.org/10.1080/1540496X.2020.1784719.

Socrates, M. K., \& Lashitew, A. A. (2020). The effect of lockdown policies on international trade flows from developing countries: Event study evidence from Kenya. Global Working Paper. Retrieved from https://www.wto.org/english/news_e/news20_e/rese_15dec20_e.pdf.

UNCTAD. (2020). Global trade impact of coronavirus (Covid-19) epidemic, 2020. Trade and Development Report Update. United Nations Conference on Trade and Development.

Vidya, C. T., \& Prabheesh, K. P. (2020). Implications of Covid-19 pandemic on the global trade networks. Emerging Markets Finance and Trade, 56(10), 2408-2421. Available at: https://doi.org/10.1080/1540496X.2020.1785426.

Wicaksono, B., \& Uluwiyah, A. (2020). Lesson learned from pandemic covid-19 in some macroeconomics performances perspectives. Paper presented at the National Symposium on State Finance. 
WITS. (2018). No Title. Indonesia trade statistics. Retrieved from Https://Wits.Worldbank.Org/CountryProfile/En/IDN.

WTO. (2020a). Export prohibition and restrictions information note. World Trade Organization. 1-17. Retrieved from: https://www.wto.org/english/tratop e/covid19 e/export prohibitions report e.pdf.

WTO. (2020b). Trade statistics and outlook. Press release. World Trade Organization. Retrieved from: https://www.wto.org/english/news_e/pres20_e/pr855_e.pdf.

Zhang, D., Hu, M., \& Ji, Q. (2020). Financial markets under the global pandemic of Covid-19. Finance Research Letters, 36, 101528. Available at: https://doi.org/10.1016/j.frl.2020.101528. 